\title{
Resistance of sugarcane cultivars to Diatraea saccharalis
}

\author{
Leila Luci Dinardo-Miranda(1), Ivan Antônio dos Anjos ${ }^{(1)}$, Viviane Pereira da Costa(1) and Juliano Vilela Fracasso(1) \\ (1)Instituto Agronômico, Centro de Cana-de-açúcar, Rodovia SP 333, Km 321, CEP 14001-970 Ribeirão Preto, SP, Brazil. \\ E-mail: leiladinardo@iac.sp.gov.br, iaanjos@iac.sp.gov.br, vpcosta30@yahoo.com.br, julianofracasso@iac.sp.gov.br
}

\begin{abstract}
The objective of this work was to evaluate the oviposition preference of Diatraea saccharalis and the effect of ten sugarcane cultivars on larval development. Oviposition preference was assessed under greenhouse conditions by three releases of couples of moths, with subsequent counting of egg masses and eggs per plant. In order to evaluate the effect of the cultivars on larval development, each plant was infected with about 150 eggs, and, 29 days later, the total number of internodes, number of bored internodes, number of life forms found, larval and pupal weight and length, and the width of larval head capsule were evaluated. The cultivars IACSP94-2101 and IACSP96-2042, the least preferred by D. saccharalis for oviposition, and IACSP94-2094, the most unfavorable for larvae entrance and development, show resistance to the pest.
\end{abstract}

Index terms: Saccharum, antibiosis, antixenosis, sugarcane borer.

\section{Resistência de cultivares de cana-de-açúcar a Diatraea saccharalis}

\begin{abstract}
Resumo - O objetivo deste trabalho foi avaliar a preferência de oviposição de Diatraea saccharalis e o efeito de dez cultivares de cana-de-açúcar no desenvolvimento larval. A preferência para oviposição foi avaliada em casa de vegetação, por meio de três liberações de casais da praga, com posterior contagem de posturas e de ovos em cada planta. Para avaliar o efeito das cultivares sobre o desenvolvimento da fase larval, cada planta foi infestada com cerca de 150 ovos e, após 29 dias, foram avaliados: número de entrenós totais, número de entrenós brocados, número de formas biológicas encontradas, peso e comprimento das lagartas e das pupas, e largura da cápsula cefálica das lagartas. As cultivares IACSP94-2101 e IACSP96-2042, as menos preferidas por D. saccharalis para oviposição, e IACSP94-2094, a mais desfavorável para a entrada e o desenvolvimento das lagartas no interior dos colmos, apresentam resistência ao inseto.
\end{abstract}

Termos para indexação: Saccharum, antibiose, antixenose, broca-comum.

\section{Introduction}

The sugarcane borer Diatraea saccharalis Fabr. (Lepidoptera: Crambidae) is one of the most important pests of sugarcane in Brazil and is widely distributed in sugarcane belts across the country (Dinardo-Miranda, 2008). Damage is caused by larvae tunneling into the stalks, causing the death of a large numbers of shoots, when the sugarcane plantation is young, and a sharp reduction in productivity, in more developed sugarcane crops. The infected stalks lose weight, become smaller and thinner, and many wither and die, while others are broken by the wind action. Under favorable conditions, secondary pests, such as Metamasius hemipterus (L.) (Coleoptera: Curculionidae), can also infest sugarcane stalks through the holes made by the borer, increasing losses in the field. The presence of many microorganisms is common, especially of fungi that cause the "red rot" disease, which reduces sucrose content in stalks, due to its conversion into glucose and fructose. The microorganisms present in stalks contaminate the broth, hampering industrial processes, hindering the attainment of high-quality sugar and inhibiting fermentation (Botelho \& Macedo, 2002; Dinardo-Miranda, 2008).

Studies conducted by Copersucar, SP, Brazil, in the late 1990's (Arrigoni, 2002), revealed that 1\% of bored internodes caused losses of $1.50 \%$ in stalk productivity, $0.49 \%$ in sugar productivity and $0.28 \%$ in alcohol productivity.

Although these data illustrate the economic importance of $D$. saccharalis to sugarcane crops, information on the susceptibility or resistance of currently-grown cultivars is still scarce. Most data available in the literature (Terán et al., 1985a, 1985b, 1986, 1988; Arrigoni, 1989) include cultivars that are no longer cultivated. The exceptions are the works of Araujo Junior (2008) and Demetrio et al. (2008), who assessed the damage caused by the borer in sugarcane cultivars, under conditions of natural infestation, in 
the states of Alagoas and Paraná, Brazil, respectively. Araujo Junior (2008) reported that each of the eight cultivars evaluated showed different behavior when attacked by a mixed population of $D$. flavipennella (Box) and D. saccharalis, and that the cultivar RB971755 suffered most attacks. Likewise, Demetrio et al. (2008) observed differences between the 12 analyzed cultivars in relation to borer populations inside the stalk, among which RB72454 and RB875338 showed the highest populations.

Portela et al. (2011) also assessed the infestation intensity in five sugarcane cultivars; however, the authors worked in a very low infested area, which did not allow the characterization of the cultivars.

In Brazil, the management of infested areas is based on biological control, particularly involving the larval parasitoid Cotesia flavipes (Cameron) (Hymenoptera: Braconidae) (Dinardo-Miranda, 2008). However, data on the behavior of cultivars in relation to the borer are still necessary to guide the selection of sites for population surveys and for releases of parasitoids. Furthermore, the use of resistant cultivars is a very useful tool in integrated pest management programs (Smith, 2005).

The objective of this work was to evaluate the oviposition preference of $D$. saccharalis and the effect of ten sugarcane cultivars on larval development.

\section{Materials and Methods}

The experiment was carried out at the Sugarcane Center of Instituto Agronômico (IAC), in Ribeirão Preto, SP, Brazil $\left(21^{\circ} 12^{\prime} 56^{\prime \prime} \mathrm{S}\right.$ and $47^{\circ} 52^{\prime} 38^{\prime \prime} \mathrm{W}$, at 630-m altitude), between November 2009 and March 2010.

For ovipostion preference analysis, cultivars were kept in a $200-\mathrm{m}^{2}$ greenhouse, in which the soil was prepared for planting according to liming and fertilization recommendations for the culture. Ten cultivars were evaluated: IAC86-3396, IAC91-1099, IAC93-3046, IACSP94-2101, IACSP94-2094, IACSP94-4004, IACSP95-5000, IACSP96-3060, IACSP96-2042, and SP91-1115; the latter was used as a standard because it is susceptible to the borer and is largely grown in the state of São Paulo, Brazil. In the greenhouse, 60 holes of $0.50 \times 0.50 \mathrm{~m}$ spaced by $1.5 \mathrm{~m}$ were made. Each hole represented one plot and received two sets of three buds of one of the analyzed cultivars.
Therefore, each treatment (cultivar) was repeated six times in a completely randomized block design.

Planting was done on $11 / 25 / 2009$. Approximately two months later, when plants had one or two internodes, moths were released to evaluate preference for oviposition. Three releases were made in 2010 $(1 / 25,2 / 4$, and 2/18). In each of them, 150 couples of 0.5 to 1 -day-old laboratory moths were released at five uniformly distributed points inside the greenhouse. Two to four days after each release, all sugarcane plants were inspected for eggs. The egg clusters found were counted and rated as small, intermediate or large. In order to define how many eggs each cluster contained, a total of 60 egg clusters on different plants and cultivars were photographed, 20 small, 20 intermediate and 20 large. After transferring the photos into the computer, the eggs in each cluster were counted. The number of eggs per plot was calculated considering the average number of eggs, according to the size of the cluster and the amount of egg clusters in each plot. After each counting, the eggs were destroyed.

The plants were then used for antibiosis analysis. To evaluate the effect of cultivars on the development of the insect larvae, on 2/25/2010 each plant was infested with six intermediate-size egg clusters from the laboratory. Therefore, each plot received 150 eggs, which were placed on small pieces of paper that were fixed on the leaves of the stalks, near the sheaths, with the aid of a pin. Twenty-nine days after infestation, all stalks were removed from plots and opened longitudinally to assess the total number of internodes and the number of bored internodes. The biological forms of the pest found were then counted, and the larval and pupal weight and length, and the width of larval head capsule were evaluated.

For statistical analysis, counting data were transformed into square root $(\mathrm{x}+1)$ and percentage data into arcsine square root $(\mathrm{x} / 100)$. After analysis of variance by the $\mathrm{F}$ test, means were compared by the Tukey test, at $10 \%$ probability.

\section{Results and Discussion}

According to the oviposition preference analysis, the small egg clusters contained on average 13 eggs, while the intermediate and large ones had 27 and 60 eggs, respectively. 
Considering each release, only the third one showed differences between cultivars regarding the amount of egg clusters (Table 1). In this release, the cultivar IACSP96-2042 received the lowest number of egg clusters, differing from IAC86-3396, which was the most infested. The other cultivars, including SP91-1115, used as a susceptibility standard, did not differ from IAC86-3396 or IACSP96-2042.

Although some differences were observed between cultivars in relation to the number of eggs clusters, there were no significant differences between them in the three releases regarding the number of eggs laid (Table 1).

On average, the cultivars IACSP94-2101 and IACSP96-2042 showed a lower amount of small egg clusters and total egg clusters, in comparison to IAC86-3396 (Table 1). The other cultivars, including SP91-1115, did not differ from IAC86-3396 or from IACSP94-2101 and IACSP96-2042, regarding the number of small egg clusters and total egg clusters. Cultivars did not differ in relation to the amount of intermediate and large egg clusters.

The cultivars IACSP94-2101 and IACSP96-2042 showed, not only a smaller number of egg slusters, but also a smaller number of eggs than IAC86-3396 (Table 1). The other cultivars, including SP91-1115, did not differ from IAC86-3396 or from IACSP94-2101 and IACSP96-2042, regarding the number of egg clusters and eggs.

Although Mesquita et al. (2011) did not observe significant differences in oviposition of Diatraea flavipennella in the presence of three sugarcane cultivars, differences between cultivars regarding the ability to attract adults of $D$. saccharalis to oviposition have been frequently reported on sugar cane (Terán et al., 1985a, 1985b, 1986, 1988; Sosa Junior, 1988; Arrigoni, 1989), on corn (Greco et al., 1988; Moré et al., 2003) and on sorghum (Boiça Junior \& Lara, 1983, 1993; Waquil et al., 2010). The causes for the preference are still not known, but a possible explanation is the absence of trichomes. Host trichomes affects oviposition behaviour in different species of Lepidoptera, stimulating or deterring females to lay their eggs (Ramaswamy, 1988). According to Smith (2005), trichome-based antixenosis is a very broad-based defense, including sugarcane resistance to some Pyralidae. Sosa Junior $(1988,1990)$ observed that in glabrous sugarcane cultivars the density of D. saccharalis eggs clusters per plant was higher than in pubescent cultivars. Instead Greco et al. (1988) did not observed differences in the total number of egg clusters per plant and number of eggs per plant laid by $D$. saccharalis between high pubescence and low pubescence corn cultivars. However, on high pubescence cultivar, there were more egg cluster and eggs per plant on the lower face (less hairy) than on the upper face. According to the authors, high pubescence could act as a physical barrier affecting the preference and searching behaviour of females, forcing them to choose the lower face of high pubescence cultivars for oviposition. Moré et al (2003) also observed that when a pubescence corn cultivar was used, there was an uniform distribution of egg clusters between both leaf sides on plants trough the first phenological stages, that could be associated to the fact that in young plants leaf hairs are not completely developed and hence do not interfere with the oviposition behaviour of the

Table 1. Number of small (S), intermediate (I), large (L) and total egg clusters ( $\mathrm{T}=\mathrm{S}+\mathrm{I}+\mathrm{L})$, number of eggs per plant, and average data from the three releases to assess oviposition preference of Diatraea saccharalis, in sugarcane cultivars ${ }^{(1)}$.

\begin{tabular}{|c|c|c|c|c|c|c|c|c|c|c|c|c|c|c|c|c|c|c|c|c|}
\hline \multirow[t]{2}{*}{ Cultivar } & \multicolumn{5}{|c|}{ First release } & \multicolumn{5}{|c|}{ Second release } & \multicolumn{5}{|c|}{ Third release } & \multicolumn{5}{|c|}{ Average } \\
\hline & $\mathrm{S}$ & I & $\mathrm{L}$ & $\mathrm{T}$ & Eggs & $\mathrm{S}$ & $\mathrm{I}$ & $\mathrm{L}$ & $\mathrm{T}$ & Eggs & $\mathrm{S}$ & I & $\mathrm{L}$ & $\mathrm{T}$ & Eggs & $\mathrm{S}$ & I & $\mathrm{L}$ & $\mathrm{T}$ & Eggs \\
\hline IAC86-3396 & $6.3 \mathrm{a}$ & $7.0 \mathrm{a}$ & $6.3 \mathrm{a}$ & $19.7 \mathrm{a}$ & $651.3 \mathrm{a}$ & $25.3 \mathrm{a}$ & $21.7 \mathrm{a}$ & $9.5 \mathrm{a}$ & $56.5 \mathrm{a}$ & $1484.3 \mathrm{a}$ & $23.3 \mathrm{a}$ & $10.7 \mathrm{a}$ & $7.8 \mathrm{a}$ & $41.8 \mathrm{a}$ & $1061.3 \mathrm{a}$ & $18.3 \mathrm{a}$ & $13.1 \mathrm{a}$ & $7.9 \mathrm{a}$ & $39.3 \mathrm{a}$ & $1065.7 \mathrm{a}$ \\
\hline IAC91-1099 & $4.7 \mathrm{a}$ & $4.8 \mathrm{a}$ & $7.3 \mathrm{a}$ & $16.8 \mathrm{a}$ & $631.2 \mathrm{a}$ & $29.7 \mathrm{a}$ & $20.3 \mathrm{a}$ & $6.2 \mathrm{a}$ & $56.1 \mathrm{a}$ & $1304.7 \mathrm{a}$ & $12.8 \mathrm{a}$ & $9.0 \mathrm{a}$ & $4.8 \mathrm{a}$ & $26.7 \mathrm{ab}$ & $699.8 \mathrm{a}$ & $15.7 \mathrm{ab}$ & $11.4 \mathrm{a}$ & $6.1 \mathrm{a}$ & $33.2 \mathrm{ab}$ & $878.6 \mathrm{ab}$ \\
\hline IACSP93-3046 & $6.5 \mathrm{a}$ & $4.3 \mathrm{a}$ & $5.8 \mathrm{a}$ & $16.7 \mathrm{a}$ & $551.5 \mathrm{a}$ & $17.2 \mathrm{a}$ & $15.8 \mathrm{a}$ & $7.5 \mathrm{a}$ & $40.5 \mathrm{a}$ & $1100.7 \mathrm{a}$ & $20.0 \mathrm{a}$ & $10.5 \mathrm{a}$ & $8.5 \mathrm{a}$ & $39.0 \mathrm{ab}$ & $1053.5 \mathrm{a}$ & $14.6 \mathrm{ab}$ & $10.2 \mathrm{a}$ & $7.3 \mathrm{a}$ & $32.1 \mathrm{ab}$ & $901.9 \mathrm{ab}$ \\
\hline IACSP94-2101 & $4.7 \mathrm{a}$ & $6.0 \mathrm{a}$ & $5.2 \mathrm{a}$ & $15.8 \mathrm{a}$ & $532.7 \mathrm{a}$ & $11.7 \mathrm{a}$ & $9.7 \mathrm{a}$ & $4.0 \mathrm{a}$ & $25.3 \mathrm{a}$ & $652.7 \mathrm{a}$ & $9.5 \mathrm{a}$ & $5.5 \mathrm{a}$ & $4.3 \mathrm{a}$ & $19.3 \mathrm{ab}$ & $532.0 \mathrm{a}$ & $8.6 b$ & 7.1a & $4.5 \mathrm{a}$ & $20.2 b$ & $572.4 \mathrm{~b}$ \\
\hline IACSP94-2094 & $5.7 \mathrm{a}$ & $4.8 \mathrm{a}$ & $4.5 \mathrm{a}$ & $15.0 \mathrm{a}$ & $474.2 \mathrm{a}$ & $15.2 \mathrm{a}$ & $12.5 \mathrm{a}$ & $6.2 \mathrm{a}$ & $33.8 \mathrm{a}$ & $904.7 \mathrm{a}$ & $14.8 \mathrm{a}$ & $8.5 \mathrm{a}$ & $6.3 \mathrm{a}$ & $29.7 \mathrm{ab}$ & $802.3 \mathrm{a}$ & $11.9 \mathrm{ab}$ & $8.6 \mathrm{a}$ & $5.7 \mathrm{a}$ & $26.2 \mathrm{ab}$ & $727.1 \mathrm{ab}$ \\
\hline IACSP94-4004 & $6.3 \mathrm{a}$ & $6.0 \mathrm{a}$ & $5.5 \mathrm{a}$ & $17.8 \mathrm{a}$ & $574.3 \mathrm{a}$ & $13.3 \mathrm{a}$ & $14.7 \mathrm{a}$ & $5.0 \mathrm{a}$ & $33.0 \mathrm{a}$ & $869.3 a$ & $11.1 \mathrm{a}$ & $7.3 \mathrm{a}$ & $5.8 \mathrm{a}$ & $23.7 \mathrm{ab}$ & $693.2 \mathrm{a}$ & $10.3 \mathrm{ab}$ & $9.3 \mathrm{a}$ & $5.4 \mathrm{a}$ & $25.1 \mathrm{ab}$ & $712.3 \mathrm{ab}$ \\
\hline IACSP95-5000 & $6.3 \mathrm{a}$ & $7.5 \mathrm{a}$ & $8.7 \mathrm{a}$ & $22.5 \mathrm{a}$ & $804.8 \mathrm{a}$ & $12.5 \mathrm{a}$ & $14.2 \mathrm{a}$ & $4.8 \mathrm{a}$ & $31.5 \mathrm{a}$ & $835.0 \mathrm{a}$ & $11.0 \mathrm{a}$ & $9.7 \mathrm{a}$ & $6.3 \mathrm{a}$ & $27.0 \mathrm{ab}$ & $784.0 \mathrm{a}$ & $9.9 \mathrm{ab}$ & $10.4 \mathrm{a}$ & $6.6 \mathrm{a}$ & $27.0 \mathrm{ab}$ & $807.9 \mathrm{ab}$ \\
\hline IACSP96-3060 & $6.0 \mathrm{a}$ & $6.5 \mathrm{a}$ & $7.3 \mathrm{a}$ & $19.8 \mathrm{a}$ & $693.5 \mathrm{a}$ & $24.2 \mathrm{a}$ & $18.7 \mathrm{a}$ & $4.7 \mathrm{a}$ & $47.5 \mathrm{a}$ & $1098.2 \mathrm{a}$ & $11.0 \mathrm{a}$ & $7.8 \mathrm{a}$ & $4.8 \mathrm{a}$ & $23.6 \mathrm{ab}$ & $644.5 \mathrm{a}$ & $13.7 \mathrm{ab}$ & $11.0 \mathrm{a}$ & $5.6 \mathrm{a}$ & $30.3 \mathrm{ab}$ & $812.1 \mathrm{ab}$ \\
\hline IACSP96-2042 & $5.2 \mathrm{a}$ & $5.0 \mathrm{a}$ & $5.2 \mathrm{a}$ & $15.3 \mathrm{a}$ & $515.2 \mathrm{a}$ & $10.7 \mathrm{a}$ & $12.5 \mathrm{a}$ & $5.8 \mathrm{a}$ & $29.0 \mathrm{a}$ & $826.2 \mathrm{a}$ & $9.5 \mathrm{a}$ & $4.3 \mathrm{a}$ & $4.1 \mathrm{a}$ & $18.0 \mathrm{~b}$ & $490.5 \mathrm{a}$ & $8.4 \mathrm{~b}$ & $7.3 \mathrm{a}$ & $5.1 \mathrm{a}$ & $20.7 b$ & $609.6 \mathrm{~b}$ \\
\hline SP91-1115 & $5.8 \mathrm{a}$ & $6.2 \mathrm{a}$ & $6.5 \mathrm{a}$ & $18.5 \mathrm{a}$ & $632.3 \mathrm{a}$ & $24.3 \mathrm{a}$ & $19.7 \mathrm{a}$ & $7.5 \mathrm{a}$ & $51.5 \mathrm{a}$ & $1297.3 \mathrm{a}$ & $9.7 \mathrm{a}$ & $5.5 \mathrm{a}$ & $6.0 \mathrm{a}$ & $21.2 \mathrm{ab}$ & $634.2 \mathrm{a}$ & $13.3 \mathrm{ab}$ & $10.4 \mathrm{a}$ & $6.7 \mathrm{a}$ & $30.4 \mathrm{ab}$ & $854.6 \mathrm{ab}$ \\
\hline$\overline{C V(\%)}$ & 23.4 & 22.5 & 31.1 & 22.6 & 28.2 & 27.5 & 26.0 & 31.2 & 23.4 & 24.8 & 29.7 & 24.9 & 31.6 & 23.2 & 26.5 & 35.3 & 32.3 & 30.4 & 28.7 & 28.5 \\
\hline
\end{tabular}

${ }^{(1)}$ Means followed by equal letters, in the columns, do not differ by the Tukey test, at $10 \%$ probability. 
females. However, in plants with phenological stages older, the abaxial surface was preferred by females for egg laying. Among the studied cultivars, IAC86-3396 and IACSP94-2101 do not have trichomes, while IAC91-1099 and IACSP96-2042 show dense growth of trichomes on leaves. Since there was no correlation between the presence of trichomes and the amount of eggs, others factors probably had a more important role in oviposition preference, such as attractants and arrestant substances.

In antibiosis analysis, although each plant had been infested with approximately 150 eggs, no more than 13.5 biological forms (larvae + pupae) of the pest, on average, were found per plant (Table 2), indicating that the deaths of most of the eggs and young larvae could have occurred due to high temperatures in the greenhouse and to antixenosis effects. Part of the eggs and young larvae could have been preyed, similarly to what occurs in nature. According to Terán (2009), in São Paulo, Brazil, natural enemies can destroy up to $86 \%$ of the eggs laid by the sugarcane borer.

The great predation of eggs and the consequent small recovery of biological forms inside the stalks were also observed by Terán et al. (1985a) and Arrigoni (1989), in studies conducted in greenhouses. These authors reported that larvae and pupae inside the stalks accounted for only about $2 \%$ of eggs laid on plants.

In the present study, larvae and pupae were found inside the stalks (Table 2). The number of pupae did not differ between the cultivars evaluated, but a significant

Table 2. Number of larvae, pupae and total of biological forms of Diatraea saccharalis found in stalks per sugarcane plant $^{(1)}$.

\begin{tabular}{lcccc}
\hline Cultivar & $\begin{array}{c}\text { Number of } \\
\text { larvae }\end{array}$ & $\begin{array}{c}\text { Number of } \\
\text { pupae }\end{array}$ & Total & $\begin{array}{c}\text { Percentage of } \\
\text { pupae }\end{array}$ \\
\hline IAC86-3396 & $5.7 \mathrm{ab}$ & $3.5 \mathrm{a}$ & $9.2 \mathrm{ab}$ & $45.8 \mathrm{a}$ \\
IAC91-1099 & $4.5 \mathrm{ab}$ & $4.8 \mathrm{a}$ & $9.3 \mathrm{ab}$ & $49.8 \mathrm{a}$ \\
IACSP93-3046 & $5.2 \mathrm{ab}$ & $5.1 \mathrm{a}$ & $10.3 \mathrm{ab}$ & $50.2 \mathrm{a}$ \\
IACSP94-2101 & $6.0 \mathrm{ab}$ & $4.7 \mathrm{a}$ & $10.7 \mathrm{ab}$ & $41.7 \mathrm{a}$ \\
IACSP94-2094 & $2.2 \mathrm{~b}$ & $5.8 \mathrm{a}$ & $8.0 \mathrm{~b}$ & $70.8 \mathrm{a}$ \\
IACSP94-4004 & $4.3 \mathrm{ab}$ & $7.2 \mathrm{a}$ & $11.5 \mathrm{ab}$ & $56.9 \mathrm{a}$ \\
IACSP95-5000 & $4.2 \mathrm{ab}$ & $4.1 \mathrm{a}$ & $8.3 \mathrm{ab}$ & $51.3 \mathrm{a}$ \\
IACSP96-3060 & $8.8 \mathrm{a}$ & $4.7 \mathrm{a}$ & $13.5 \mathrm{a}$ & $36.8 \mathrm{a}$ \\
IACSP96-2042 & $6.5 \mathrm{ab}$ & $3.2 \mathrm{a}$ & $9.7 \mathrm{ab}$ & $37.6 \mathrm{a}$ \\
SP91-1115 & $3.0 \mathrm{ab}$ & $5.8 \mathrm{a}$ & $8.8 \mathrm{ab}$ & $62.6 \mathrm{a}$ \\
\hline CV (\%) & 30.5 & 16.2 & 30.3 & 47.8 \\
\hline
\end{tabular}

(1) Means followed by equal letters, in the columns, do not differ by the Tukey test, at $10 \%$ probability. difference was observed between cultivars regarding the number of larvae in the stalks. The lowest number was found in the cultivar IACSP94-2094 and the highest in IACSP96-3060.

The largest number of biological forms (larvae + pupae) was also found in the cultivar IACSP96-3060 and the lowest in IACSP94-2094, which differed significantly between each other. The other cultivars showed intermediate values (Table 2).

Among the ten tested cultivars, the non-preferred for oviposition were: IACSP94-2101 and IACSP96-2042, while the preferred cultivar was IAC86-3396. However, since the same number of eggs was laid on each plant, the largest number of biological forms was found in cultivars IACSP96-3060 and IACSP94-4004, but not in IAC86-3396, corroborating Lara (1991), according to which the preferred cultivar for oviposition does not always allow the development of a greater number of larvae. In fact, Terán et al. (1985a), in a study with six sugarcane cultivars, observed that NA56-79 received the smallest number of $D$. saccharalis eggs, while IAC52-150 was preferred for oviposition. However, these authors also reported that the survival of larvae was significantly higher in the cultivar NA56-79 $(41.7 \%)$ than in IAC $52-150(25.0 \%)$. While evaluating other sugarcane cultivars, Terán et al. (1988) observed that SP71-6163, preferred for oviposition, also allowed a greater survival of larvae, among the tested cultivars.

Since the same number of eggs was laid on each plant, a possible reason for the differences among cultivars in relation to number of biological forms within the stalks would be the presence of trichomes on leaves. Sosa Junior (1988) observed that trichomes on sugarcane leaves delay first instar larval movement, wich should increase larval mortality by increasing exposure to adverse environmental and biological factors. However, in this study, the lowest number of biological forms of the pest was found in the cultivar IACSP94-2094, and the largest was observed in IACSP96-3060, both cultivars with few trichomes. Therefore, the latter probably has a larger amount of exciting substances or a smaller amount of suppressant substances in comparison to the other cultivars, while IACSP94-2094 probably has higher concentrations of suppressant substances or lower concentrations of exciting substances.

Although the percentage of pupae per cultivar varied from 36.8 (IACSP96-3060) to 70.8 (IACSP94-2094), 
these differences were not significant (Table 2). At first glance, there was no significant change in the length of the larval stage due to the host; however, since the dates on which larvae became pupae were not recorded, it is not possible to infer whether or not there was interference from the host on the length of the larval stage.

No significant differences were observed in relation to the weight and length of pupae and the width of the head capsules of larvae found in the different cultivars (Table 3). However, significant differences were observed in relation to the weight and length of larvae: larvae that fed on IACSP94-2094 and IACSP96-3060 weighed significantly less than larvae that fed on SP91-1115. Besides being heavier, larvae found in SP91-1115 also showed greater length than those found in the cultivars IACSP96-3060 and IACSP96-2042.

The total number of bored internodes and the number of bored internodes by biological form also varied according to the cultivar (Table 4). The highest rates were reported for IACSP94-2101, while IACSP94-2094 had the lowest total number of bored internodes. This cultivar, followed by IACSP95-5000 and IACSP96-3060, also presented the lowest number of bored internodes by biological forms.

The cultivar IACSP94-2094 probably has a suppressant component, which inhibits the penetration of larvae in the stalk, besides substances with some degree of deterrence, since both the total number of bored internodes and the number of bored internodes by biological form were smaller than in the other cultivars.

Table 3. Weight, body length and width of head capsules (HC) of larvae and weight and length of pupae of Diatraea saccharalis found in stalks ${ }^{(1)}$.

\begin{tabular}{lcccccc}
\hline Cultivar & \multicolumn{3}{c}{ Larvae } & & \multicolumn{2}{c}{ Pupae } \\
\cline { 2 - 3 } \cline { 6 - 7 } & $\begin{array}{c}\text { Weight } \\
(\mathrm{mg})\end{array}$ & Length & HC & & $\begin{array}{c}\text { Weight } \\
(\mathrm{mg})\end{array}$ & $\begin{array}{c}\text { Length } \\
(\mathrm{mm})\end{array}$ \\
\hline IAC86------ $(\mathrm{mm})$ & ------- & & & \\
& $85.6 \mathrm{ab}$ & $17.52 \mathrm{ab}$ & $1.81 \mathrm{a}$ & & $84.3 \mathrm{a}$ & $14.46 \mathrm{a}$ \\
IAC91-1099 & $85.8 \mathrm{ab}$ & $18.00 \mathrm{ab}$ & $1.80 \mathrm{a}$ & & $87.8 \mathrm{a}$ & $15.72 \mathrm{a}$ \\
IACSP93-3046 & $81.5 \mathrm{ab}$ & $18.61 \mathrm{ab}$ & $1.90 \mathrm{a}$ & & $92.7 \mathrm{a}$ & $15.95 \mathrm{a}$ \\
IACSP94-2101 & $70.6 \mathrm{ab}$ & $17.13 \mathrm{ab}$ & $1.80 \mathrm{a}$ & & $84.2 \mathrm{a}$ & $14.63 \mathrm{a}$ \\
IACSP94-2094 & $47.6 \mathrm{~b}$ & $17.02 \mathrm{ab}$ & $1.75 \mathrm{a}$ & & $73.0 \mathrm{a}$ & $17.20 \mathrm{a}$ \\
IACSP94-4004 & $76.1 \mathrm{ab}$ & $19.04 \mathrm{ab}$ & $1.73 \mathrm{a}$ & & $84.0 \mathrm{a}$ & $14.51 \mathrm{a}$ \\
IACSP95-5000 & $72.9 \mathrm{ab}$ & $17.01 \mathrm{ab}$ & $1.71 \mathrm{a}$ & & $76.8 \mathrm{a}$ & $14.17 \mathrm{a}$ \\
IACSP96-3060 & $60.3 \mathrm{~b}$ & $15.62 \mathrm{~b}$ & $1.74 \mathrm{a}$ & & $67.6 \mathrm{a}$ & $13.75 \mathrm{a}$ \\
IACSP96-2042 & $75.8 \mathrm{ab}$ & $16.73 \mathrm{~b}$ & $1.80 \mathrm{a}$ & & $79.8 \mathrm{a}$ & $14.60 \mathrm{a}$ \\
SP91-1115 & $102.5 \mathrm{a}$ & $21.27 \mathrm{a}$ & $1.95 \mathrm{a}$ & & $102.6 \mathrm{a}$ & $15.60 \mathrm{a}$ \\
\hline CV (\%) & 23.8 & 11.6 & 9.3 & & 25.4 & 9.1 \\
\hline
\end{tabular}

${ }^{(1)}$ Means followed by equal letters, in the columns, do not differ by the Tukey test, at $10 \%$ probability.
In this cultivar, the larvae weighed less than those found in SP91-1115, indicating that IACSP94-2094 may also exhibit antibiosis resistance. Indeed, it is difficult to distinguish how much of the effect is due to deterrence or to antibiosis (Lara, 1991; Smith, 2005).

Although the cultivar IACSP96-3060 showed more biological forms of the pest in its stalks, indicating that it probably has greater amounts of exciting substances or lower concentrations of suppressant substances than the other cultivars, it hampered the development of the insect, since larvae fed on this cultivar were smaller and weighed less than those found in SP91-1115. The consumption of internodes by biological forms was also lower than in the other cultivars, indicating that IACSP96-3060 also shows some degree of deterrence or antibiosis. White et al. (2011) also suggested antibiosis as a mechanism of resistance to the sugarcane borer in two genotypes from Louisiana breeding program, since they observed low adult emergence and low larval weights in insects from those cultivars.

The damage caused by the pest can be assessed by infestation intensity rates, expressed as the percentage of bored internodes. The highest rates were observed in the cultivar IACSP94-4004 and IACSP94-2101, while the lowest were found in IACSP94-2094 and IACSP95-5000 (Table 4). Differences among sugarcane cultivars regarding the infestation intensity of $D$. saccharalis were detected by several researchers, such as Téran et al., 1985a, 1985b, 1986, 1988, White et al., 1996, 1998, 2006; Demetrio et al., 2008; Ramón

Table 4. Number of bored internodes in each plant and by biological forms of Diatraea saccharalis, and percentage of bored internodes each cultivar.

\begin{tabular}{lccc}
\hline Cultivar & $\begin{array}{c}\text { Bored internodes } \\
\text { per plant }\end{array}$ & $\begin{array}{c}\text { Bored internodes } \\
\text { by biological } \\
\text { forms }\end{array}$ & $\begin{array}{c}\text { Bored internodes } \\
(\%)\end{array}$ \\
\hline IAC86-3396 & $38.7 \mathrm{abc}$ & $4.2 \mathrm{ab}$ & $36.0 \mathrm{bcde}$ \\
IAC91-1099 & $34.0 \mathrm{abc}$ & $3.7 \mathrm{ab}$ & $34.9 \mathrm{bcde}$ \\
IACSP93-3046 & $33.7 \mathrm{abc}$ & $3.3 \mathrm{ab}$ & $37.9 \mathrm{bcde}$ \\
IACSP94-2101 & $52.2 \mathrm{a}$ & $5.2 \mathrm{a}$ & $63.5 \mathrm{ab}$ \\
IACSP94-2094 & $18.3 \mathrm{c}$ & $2.3 \mathrm{~b}$ & $17.8 \mathrm{e}$ \\
IACSP94-4004 & $43.2 \mathrm{ab}$ & $4.5 \mathrm{ab}$ & $73.0 \mathrm{a}$ \\
IACSP95-5000 & $23.0 \mathrm{bc}$ & $2.8 \mathrm{~b}$ & $27.2 \mathrm{de}$ \\
IACSP96-3060 & $39.2 \mathrm{abc}$ & $2.8 \mathrm{~b}$ & $30.4 \mathrm{cde}$ \\
IACSP96-2042 & $39.5 \mathrm{abc}$ & $4.5 \mathrm{ab}$ & $59.2 \mathrm{abc}$ \\
SP91-1115 & $31.8 \mathrm{abc}$ & $3.7 \mathrm{ab}$ & $49.6 \mathrm{abcd}$ \\
\hline CV (\%) & 20.5 & 22.7 & 14.1 \\
\hline (1)Means followed by equal letters, in the columns, do not differ by the \\
Tukey test, at 10\% probability.
\end{tabular}

Pesq. agropec. bras., Brasília, v.47, n.1, p.1-7, jan. 2012 
et al., 2008, Souza et al., 2008. In this study, it is important to highlight that IACSP94-2094, considered a cultivar of fast growth, not only showed a smaller number of larvae and of bored internodes by biological forms, but also a larger number of internodes - 103 per clump, while the average was 88 internodes per clump -, which contributed to reduce, in proportional terms, the damage caused by the borer. Therefore, the fast growth of this cultivar contributed to a greater degree of tolerance to the pest than slower-growing cultivars, such as IACSP94-4004, which had many internodes consumed by the borer and only a few (59 per clump) resulted in higher infestation rates. However, the infestation intensity rates in all cultivars were extremely high, since many researchers consider that the level of economic damage caused by the pest is between 2 and $4 \%$ of bored internodes (Botelho \& Macedo, 2002; Pinto et al., 2006).

\section{Conclusion}

IACSP94-2101 and IACSP96-2042, the least preferred cultivars by Diatraea saccharalis for oviposition, and IACSP94-2094, the most unfavorable for larvae entrance and development, show resistance to the pest.

\section{Acknowledgments}

To Fundação de Amparo à Pesquisa do Estado de São Paulo, for financial support; and to the biological control company Biocontrol, for donation of Diatraea saccharalis biological material.

\section{References}

ARAUJO JUNIOR, J.V. de. Avaliação de variedades RB (República do Brasil) em relação ao ataque das principais pragas da cana-de-açúcar em Rio Largo, Estado de Alagoas. 2008. 86p. Dissertação (Mestrado) - Universidade Federal de Alagoas, Maceió.

ARRIGONI, E. de B. Broca da cana-de-açúcar - importância econômica e situação atual. In: ARRIGONI, E. de B.; DINARDO-MIRANDA, L.L.; ROSSETO, R. Pragas da cana-de-açúcar - importância econômica e enfoques atuais. Piracicaba: STAB, 2002. p.1-4.

ARRIGONI, E. de B. Estudos sobre resistência da cana à broca em telado - V. Boletim Técnico Copersucar, v.48, p.25-31, 1989.

BOIÇA JR, A.L.; LARA, F.M. Avaliação da resistência de genótipos de Sorghum bicolor (L.) Moench a Diatraea saccharalis (Fabricius, 1794) (Lepidoptera, Pyralidae) e determinação dos tipos envolvidos. Anais da Sociedade Entomológica do Brasil, v.12, n.2, p.261-272, 1983.

BOIÇA JR, A.L.; LARA, F.M. Resistência de genótipos de sorgo ao ataque de Diatraea saccharalis (Fabr.) (Lepidoptera, Pyralidae). Anais da Sociedade Entomológica do Brasil, v.22, n.2, p.245-252, 1993.

BOTELHO, P.S.M.; MACEDO, N. Cotesia flavipes para o controle de Diatraea saccharalis. In: PARRA, J.R.P.; BOTELHO, P.S.M.; CORREAA-FERREIRA, B.S.; BENTO, J.M.S. Controle biológico no Brasil: parasitóides e predadores. São Paulo: Manole, 2002. p.409-425.

DEMETRIO, P.A.; ZONETTI, P.P.; MUNHOZ, R.E.F. Avaliação de clones de cana-de-açúcar promissores RBs quanto à resistência à broca-da-cana (Diatraea saccharalis) na região noroeste do Paraná. Iniciação Científica Cesumar, v.10, p.13-16, 2008.

DEMETRIO, P.A.; ZONETTI, P.P.; MUNHOZ, R.E.F. Avaliação de clones de cana-de-açúcar promissores RBs quanto à resistência à broca da cana (Diatraea saccharalis) na região noroeste do Paraná. Iniciação Científica Cesumar, v.10, p.13-16, 2008.

DINARDO-MIRANDA, L.L. Pragas. In: DINARDO-MIRANDA, L.L.; VASCONCELOS, A.C.M. de; LANDELL, M.G. de A. (Ed.). Cana-de-açúcar. Campinas: Instituto Agronômico, 2008. p.349-404.

GRECO, N.M.; SARANDON, S.J.; PEREYRA, P.C. Parasitismo f Diatraea saccharalis (Lepidóptera: Pyralidae) eggs by Trichogramma exiguum (Hymenoptera, Tricogrammatidae): influence of Zea mays leaf pubescence. Ecologia Austral, v.8, n.1, p.31-35, 1998.

LARA, F.M. Princípios de resistência de plantas a insetos. 2.ed. São Paulo: Ícone, 1991. 336p.

MESQUITA, F.L.T.; MENDONÇA, A.L.; DA SILVA, C.E.; CORREIA A.M.O; SALES, D.F.M.; CABRAL JR, C.R.; DO NASCIMENTO, R.R. Influence of Saccharum officinarum (Poales: Paocae) variety on reproductive behavior of Diatraea flavipennella (Lepidoptera: CRambidade) and on the attraction of the parasitoid Cotesia flavipes (Hymenoptera: Braconidade). Florida Entomologist, v.94, n.3, p.420-427.

MESQUITA, F.L.T.; MENDONÇA, A.L.; SILVA, C.E. da; CORREIA, A.M.O; SALES, D.F.M.; CABRAL JUNIOR, C.R.; DO NASCIMENTO, R.R. Influence of Saccharum officinarum (Poales: Poaceae) variety on the reproductive behavior of Diatraea flavipennella (Lepidoptera: Crambidae) and on the attraction of the parasitoid Cotesia flavipes (Hymenoptera: Braconidae). Florida Entomologist, v.94, p.420-427, 2011.

MORÉ, M.; TRUMPER, E.V.; PROLA, M.J. Influence of corn, Zea mays, phonological stages in Diatraea saccharalis F. (Lep. Crambidae) oviposition. Journal of Applied Entomology, v.127, n.9-10, p.512-515, 2003.

PINTO, A.S.; GARCIA, J.F.; OLIVEIRA, H.N. Manejo das principais pragas da cana-de-açúcar. In: SEGATO, S.V.; PINTO, A. de S.; JENDIROBA, E.; NÓBREGA, J.C.M. de. (Org.). Atualização em produção de cana-de-açúcar. Piracicaba, 2006. p.257-280.

PORTELA, G.L.F.; PÁDUA, L.E. de M.; CASTELO BRANCO, R.T.P.; BARBOSA, O. de A.; SILVA, P.R.R. Infestação de 
Diatraea spp. em diferentes variedades de cana-de-açúcar em União - PI. Revista Caatinga, v.24, p.149-152, 2011.

RAMASWAMY, S.B. Host finding by moth: sensory modalities and behaviours. Journal of Insect Physiology, v. 34, n.3, p.235249, 1988.

RAMÓN, M.C.; MAURIELLO, F.; GRATEROL, Y.; GIRALDOVANEGAS, H.; MENDOZA, C.; PÉREZ, M.M.; IZARRAGA. R.M. Asociación entre lãs características varietales y el dano ocasionado por el taladrador de La cana de azúcar, em el estado Portuguesa, Venezuela. Agronomia Tropical, v.52, n.2, p.111-116, 2008.

SMITH, C.M. Plant resistance to arthropods: molecular and conventional approaches. The Netherlands: Springer, 2005. 423p.

SOSA JR, O. Oviposition preference by the sugarcane borer (Lepidoptera: Pyralidae). Journal of Economic Entomology, v.83, n.3, p.866-868, 1990.

SOSA JR, O. Pubescence in sugarcane as a plant resistance character affecting oviposition and mobility by the sugarcane borer (Lepidoptera; Pyralidae). Journal of Economic Entomology, v.81, n.2, p.663-667, 1988.

SOUZA, Z.M.; PAIXÃO, A.C.S.; PRADO, R.M.; CESARIN, L.G. SOUZA, S.R.; MONTANARI, R. Produtividade agrícola de variedades de cana-de-açúcar e incidência de broca-comum e cigarrinha da raiz em canavial colhido sem queima. Bragantia, v.67, n.2, p.413-419, 2008.

TERÁN, F.O. Manejo ecológico de plagas de la caña de azucar. Santa Cruz: Imprenta Tokyo, 2009. 176p.

TERÁN, F.O.; SÁNCHEZ, A.G.; PRECETTI, A.A.C.M. Estudos sobre resistência da cana à broca em telado: primeiros resultados. Boletim Técnico Copersucar, v.29, p.2-11, 1985a.

TERÁN, F.O.; SÁNCHEZ, A.G.; PRECETTI, A.A.C.M. Estudos sobre resistência da cana à broca em telado - II. Boletim Técnico Copersucar, v.33, p.57-64, 1985b.
TERÁN, F.O.; SÁNCHEZ, A.G.; PRECETTI, A.A.C.M. Estudos sobre resistência da cana à broca em telado - III. Boletim Técnico Copersucar, v.34, p.53-60, 1986.

TERÁN, F.O.; SÁNCHEZ, A.G.; PRECETTI, A.A.C.M. Estudos sobre resistência da cana à broca em telado - IV. Boletim Técnico Copersucar, v.40, p.9-14, 1988.

WAQUIL, J.M.; RODRIGUES, J.A.S.; SANTOS, F.G.; FERREIRA, A.S.; VILELLA, F.M.F.; FOSTER, J.E. Resistance of commercial hybrids and lines of sorghum, Sorghum bicolor (L.) Moench, to Diatraea saccharalis (Fabr.) (Lepidoptera; Pyralidae). Neotropical Entomology, v.30, n.4, p. 661-668, 2001.

WHITE, W.H.; BURNER, D.M.; LEGENDRE, B.L.; MILLER, J.D. Registration of 12 sugarcane germplasm clones resistant to sugarcane borer: HoCP 92-678, НоCP 93-775, НоCP 93-776, US 93-15 to US 93-17, and US 96-1 to US 96-6, Crop Science, v. 38, n.6, p.1726-1727, 1998 .

WHITE, W.H.; HALE, A.L.; VEREMIS, J.C.; TEW, T.L.; RICHARD JR, E.P. Registration of two sugarcane germoplasm clones with antibiosis to the sugarcane borer (Lepidoptera: Crambidae). Journal of Plant Registration, v.5, n.2, p.248-253, 2011.

WHITE, W.H.; HALE, A.L.; VEREMIS, J.C.; TEW, T.L.; RICHARD JR., E.P. Registration of two sugarcane germplasm clones with antibiosis to the sugarcane borer (Lepidoptera: Crambidae). Journal of Plant Registrations, v.5, p.248-253, 2011.

WHITE, W.H.; LEGENDRE, B.L.; MILLER, J.D. Progress in breeding for sugarcane borer resistance. Sugar Cane: v.5, n.1, p.3-7, 1996

WHITE, W.H.; TEW, T.L.; RICHARD JR., E.P. Association of sugarcane pith, ring hardness, and fiber with resistance to the sugarcane borer. Journal of American Society of Sugar Cane Technologists, v.26, p.87-100, 2006.

Received on February 8, 2011 and accepted on October 3, 2011 